\title{
Indywidualna opłacalność \\ kształcenia zawodowego w Polsce \\ w latach 2004-2016
}

DOI: $10.47050 / 65591814.168-191$

Leszek Wincenciak

Kwestia opłacalności kształcenia zawodowego z perspektywy indywidualnej jest niezwykle ważna w kontekście zapewniania odpowiedniej motywacji do jego podejmowania. W niniejszym rozdziale podjęto próbę odpowiedzi na pytanie o wartość kształcenia zawodowego na podstawie metodologii szacowania równania wynagrodzeń Mincera i wyceny projektów inwestycyjnych (wartość bieżąca netto, wewnętrzna stopa zwrotu). Punktem wyjścia analizy jest teoria ekonomii (teoria kapitału ludzkiego), w której wykształcenie traktowane jest jako inwestycja w kapitał ludzki. Bazując na oszacowanej wartości bieżącej strumienia dochodów w cyklu życia oraz wewnętrznej stopy zwrotu dla wykształcenia zawodowego, można stwierdzić, że powstałe na początku transformacji znaczne dysproporcje w zarobkach na niekorzyść osób z wykształceniem zawodowym po 2004 r. powoli i stopniowo zmniejszały się. Mężczyźni osiągali wyższą stopę zwrotu z kształcenia jedynie w przypadku wykształcenia zasadniczego zawodowego, przy czym dysproporcja ta w okresie 2004-2016 zmalała znacząco, gdyż zwrot z wykształcenia zawodowego dla kobiet wyraźnie wzrósł.

\section{Słowa kluczowe:}

zwrot z wykształcenia

wartość bieżąca netto

kształcenie zawodowe

Polska 


\section{Individual returns to vocational education in Poland 2004-2016}

DOI: 10.47050/65591814.168-191

Leszek Wincenciak

The issue of the profitability of vocational education from an individual perspective is extremely important from the point of view of providing the right incentives to choose this type of education. This chapter tries to answer the question of the value of vocational education based on the methodology of estimating the Mincer earnings equation (Mincer 1974) and the valuation of investment projects (net present value, internal rate of return). The background for the analysis results from economic theory (the theory of human capital), where education is treated as an investment in human capital. Basing on the estimated results for the net present value of the lifetime income and on the internal rate of return for vocational education, it can be concluded that significant disproportions in earnings at the beginning of the transformation to the disadvantage of people with vocational education were slowly and gradually reduced after 2004. Men had higher rates of return to education only in the case of basic vocational education, however, the disproportion decreased significantly in the period 2004-2016, as the return to vocational education for women increased.

\section{Keywords:}

returns to schooling

net present value

vocational education

Poland 


\section{Wprowadzenie}

System kształcenia ma za zadanie wyposażyć uczniów w niezbędną wiedzę i kompetencje do tego, aby mogli, ukończywszy dany etap edukacji, skutecznie podejmować zatrudnienie lub kontynuować kształcenie na wyższych poziomach. Kształcenie zawodowe tradycyjnie rozumiemy jako ten rodzaj edukacji, której podstawowym celem jest wyposażanie absolwentów w kompetencje bezpośrednio użyteczne z perspektywy rynku pracy. W Polsce wykształcenie zawodowe można zdobyć przede wszystkim w zasadniczych i średnich szkołach zawodowych. Mniej znaczące liczebnie są grupy, które uzyskały kompetencje zawodowe w toku kształcenia się w szkołach policealnych (wcześniej pomaturalnych) lub w kolegiach nauczycielskich, a także poprzez odbywanie kształcenia w rzemiośle czy dzięki ukończeniu odpowiednich kursów zawodowych i zdaniu egzaminów potwierdzających kwalifikacje. Ta ostatnia ścieżka praktycznie dopiero w ostatnich latach zyskuje jakiekolwiek znaczenie.

W Polsce dostęp do kształcenia zawodowego, podobnie jak i ogólnego, zapewniają przede wszystkim szkoły ponadgimnazjalne. Przed 1998 r. kształcenie w nich podejmowano bezpośrednio po szkołach podstawowych, były więc to szkoły poprzedzone krótszym o rok cyklem kształcenia ogólnego. Podobnie będzie wkrótce, gdyż w 2018 r. zlikwidowano nabór do gimnazjów i powrócono do kształcenia średniego na podbudowie ośmioletniej szkoły podstawowej. Niezależnie od wszelkich zawirowań w zakresie organizacji i programu kształcenia zawodowego, obserwujemy istotny spadek udziału osób posiadających wykształcenie zawodowe w dorosłej populacji Polaków.

Jedną z hipotez wyjaśniających osłabienie zainteresowania uzyskiwaniem wykształcenia zawodowego może być zmieniająca się pozycja na rynku pracy osób z tej grupy. Kwestia opłacalności takiego kształcenia z perspektywy indywidualnej jest niezwykle ważna w kontekście zapewniania odpowiedniej motywacji do jego podejmowania. Temu zagadnieniu poświęcony jest niniejszy rozdział. Aby odpowiedzieć na pytanie, jaka jest wartość kształcenia w ogólności, a kształcenia zawodowego w szczególności, należy przyjąć pewną metodologię badania i poczynić odpowiednie założenia. Jako ramę analizy przyjęto w niniejszym opracowaniu sposób szacowania wartości edukacji zaczerpnięty z metodologii wyceny projektów inwestycyjnych. Jest to w dużym stopniu uzasadnione, gdyż z perspektywy ekonomicznej (teoria kapi- 
tału ludzkiego) wykształcenie może być postrzegane jako inwestycja w kapitał ludzki.

Wartość kształcenia została policzona jako wartość bieżąca netto strumienia korzyści, którą generuje dany rodzaj wykształcenia. Ponieważ jest to wartość netto, to do jej obliczenia konieczna jest znajomość kosztów (ponoszonych nakładów inwestycyjnych) oraz korzyści, którymi są dochody z pracy zarobkowej. Ze względu na to, że jest to wartość bieżąca (na dany moment), to do jej obliczenia potrzebne jest przyjęcie pewnej wartości stopy dyskontowej. Najczęściej w tego typu opracowaniach przyjmowaną wartością jest 3\% i dlatego zdecydowano się przyjąć ją również w niniejszej pracy. Przy obliczaniu wartości bieżącej netto korzyści dla danego poziomu wykształcenia konieczne jest ustalenie pewnego poziomu referencyjnego, względem którego dana wielkość będzie szacowana. W przypadku wykształcenia zasadniczego zawodowego oraz średniego zawodowego poziomem odniesienia będzie poziom wykształcenia co najwyżej gimnazjalny. Dodatkowo, dla porównania, obliczono analogiczne wartości dla wykształcenia średniego ogólnego (z tym samym poziomem referencyjnym) oraz wykształcenia wyższego (z poziomem referencyjnym, którym jest wykształcenie średnie ogólne). Z analizy wyłączono kolegia nauczycielskie i szkoły policealne. Szczególnie ważne jest porównanie korzyści z wykształcenia średniego ogólnego, bowiem po ukończeniu gimnazjum uczeń miał do wyboru trzy główne ścieżki edukacyjne: technikum (lub inną średnią szkołę zawodową), zasadniczą szkołę zawodową i liceum ogólnokształcące. Zakładamy, że opłacalność kształcenia mogła mieć wpływ na ten wybór. Z kolei analiza korzyści płynących z wykształcenia wyższego pozwala zrozumieć, że w przypadku osób kontynuujących kształcenie po szkole średniej korzyści z edukacji kumulowały się, co także mogło wpływać na wybór ścieżki edukacyjnej młodzieży. Z powodu niemożliwości rozdzielenia wykształcenia wyższego I i ll stopnia oraz studiów jednolitych w danych za 2004 r., stanowiący punkt początkowy analizy, zdecydowano się kategoryzować wykształcenie wyższe bez tego podziału, de facto uśredniając poziom korzyści dla osób, które skończyły studia I lub II stopnia albo jednolite. Z punktu widzenia rozważań na temat opłacalności podjęcia kształcenia zawodowego (w szkole średniej lub zasadniczej) jest to zabieg w pełni zasadny. 
Poniższy rozdział poświęcono identyfikacji indywidualnych determinant wynagrodzeń osób z wykształceniem zawodowym oraz czynników decydujących o zatrudnialności tychże osób.

W tym celu przeprowadzono sformalizowaną analizę z następującymi założeniami:

$\rightarrow$ Wykształcenie wyższe obejmuje I i ll stopień oraz studia jednolite.

$\rightarrow$ Wykształcenie zawodowe obejmuje jedynie absolwentów zasadniczych i średnich szkół zawodowych.

$\rightarrow$ Wyłączono $z$ analizy szkoły policealne i kolegia nauczycielskie, których liczba absolwentów jest stosunkowo nieduża.

$\rightarrow$ Badaniem wynagrodzeń objęto wyłącznie osoby niekontynuujące kształcenia.

Analiza przebiegała w trzech etapach. Najpierw oszacowano rozszerzone równanie płac Mincera (Mincer 1974) dla rocznych zarobków netto, uzyskując parametry, dzięki którym możliwe jest wygenerowanie wygładzonych ścieżek dochodów w cyklu życia dla osób legitymujących się poszczególnymi poziomami wykształcenia. Na drugim etapie oszacowano model logitowy prawdopodobieństwa zatrudnienia, dzięki któremu możliwe było wygenerowanie ścieżek prawdopodobieństwa wykonywania pracy zarobkowej w cyklu życia dla osób o różnych poziomach wykształcenia. Na etapie trzecim wygenerowano wartości dopasowane $z$ dwóch powyższych modeli dla poszczególnych kohort i poziomów wykształcenia. Pozwoliło to następnie obliczyć oczekiwaną wartość bieżącą netto danego typu wykształcenia oraz wewnętrzną stopę zwrotu, która umożliwiła ocenę opłacalności inwestowania w kształcenie danego typu. Posługiwano się danymi z Badania Aktywności Ekonomicznej Ludności za lata 2004, 2008, 2012 i 2016.

\section{Model wynagrodzeń i prawdopodobieństwa pracy}

Pierwszym etapem analizy było sformułowanie rozszerzonego równania płac Mincera dla rocznych zarobków netto, które wyjaśniano w regresji następującym zestawem zmiennych objaśniających: płeć, poziom wykształcenia (wyższe, średnie zawodowe, średnie ogólne, zasadnicze zawodowe, gimnazjalne i poniżej), wiek, wiek podniesiony do kwadratu, województwo, klasa miejsca zamieszkania, wielkość firmy oraz sektor (publiczny, prywatny). Równanie regresji przyjęło postać: 


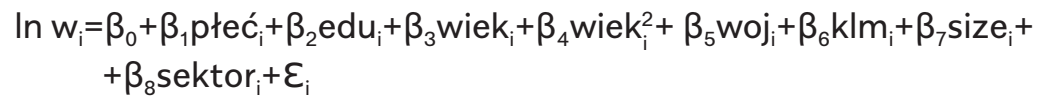

Powyższy model oszacowano metodą najmniejszych kwadratów.

W drugim etapie oszacowano model logitowy prawdopodobieństwa zatrudnienia, które objaśniano następującym zestawem zmiennych: płeć, poziom wykształcenia (analogicznie jak wyżej), wiek (wielomian czwartego stopnia - ze względu na lepsze dopasowanie do danych empirycznych), województwo, stan cywilny oraz klasa miejsca zamieszkania.

$$
\begin{aligned}
\operatorname{Pr}\left(S_{i}=1\right)= & f\left(\gamma_{0}+\gamma_{1} p_{\text {tec }}+\gamma_{2} \text { edu }_{i}+\gamma_{3} \text { wiek }_{i}+\gamma_{4} \text { wieki }_{i}^{2}+\gamma_{5} \text { wiek }_{i}^{3}+\gamma_{6} \text { wiek }_{i}^{4}+\right. \\
& \left.+\gamma_{7} w_{0} j_{i}+\gamma_{8} \text { stc }_{i}+\gamma_{9} k l m_{i}+\varepsilon_{i}\right)
\end{aligned}
$$

Model prawdopodobieństwa szacowano metodą największej wiarogodności.

\section{Założenia metodologiczne}

\section{Zasadnicze szkoły zawodowe}

Do obliczenia wartości bieżącej netto dla danego poziomu wykształcenia konieczne jest poczynienie szeregu założeń. Dla osoby, która ukończyła zasadniczą szkołę zawodową i nie kontynuuje kształcenia, wartość bieżąca netto została obliczona według formuły:

$$
N P V z s z=-\sum_{t=1}^{3} \frac{C_{t}^{z s z}}{(1+r)^{t}}+\sum_{t=4}^{50} \frac{B_{t}^{z s z}}{(1+r)^{t}}
$$

Zakłada ona, że strumień korzyści - $\mathrm{B}_{\mathrm{t}}^{\mathrm{z} z z}$ - przez pierwsze trzy lata (dla t $=1,2,3$ ) wynosi zero. Odzwierciedla się $w$ ten sposób okres nauki, w trakcie której (dla uproszczenia) zakłada się, że uczeń nie wykonuje pracy przynoszącej dochód, co zmienia się wraz z ukończeniem szkoły.

Strumieniem kosztów w trakcie nauki - $\mathrm{C}_{\mathrm{t}}^{z s z}$ - jest zaś koszt alternatywny, czyli korzyści, których kształcący się uczeń nie otrzyma, ponieważ w trakcie nauki nie wykonuje pracy zarobkowej. Te utracone korzyści z pracy odpowiadają oczekiwanym dochodom uzyskiwanym z pracy wykonywanej przez osoby z wykształceniem gimnazjalnym i poniżej. 
Przez oczekiwane dochody należy rozumieć iloczyn rocznego dochodu z pracy i prawdopodobieństwa zatrudnienia, co obrazuje zróżnicowane szanse na uzyskiwanie dochodu dla osób z różnymi poziomami wykształcenia.

Poza tym w uproszczeniu przyjęto, że uczeń nie ponosi żadnych bezpośrednich (finansowych) kosztów zdobywania wykształcenia, choć jak wiadomo, nawet bezpłatne kształcenie wiąże się z wydatkami uczniów i ich rodzin (Sztanderska, Grotkowska 2017).

Założono, że osoba wchodząca na rynek pracy z wykształceniem zasadniczym zawodowym rozpoczyna zarobkowanie w 16 . roku życia i kontynuuje karierę zawodową do 65. roku życia, stąd horyzont dyskontowania korzyści od $\mathrm{t}=4 \mathrm{dot}=50$. We wszystkich obliczeniach wartości bieżącej netto przyjęto stopę dyskontową na poziomie $3 \%$.

Dla powyższej formuły na wartość bieżącą netto można numerycznie wyznaczyć taką wartość stopy dyskontowej ř, która sprawia, że NPV $=0$. Wartość tę nazywa się wewnętrzną stopą zwrotu z inwestycji. Zachodzi własność, że dla każdego $r<$ r wartość NPV > 0, co czyni inwestycję opłacalną. Każda inwestycja, której NPV jest nieujemne, może zostać uznana za atrakcyjną. Dodatkowo wartość wewnętrznej stopy zwrotu można interpretować w relacji do kosztu kredytu, który trzeba byłoby zaciągnąć w celu dokonania inwestycji. Aby inwestycja była opłacalna, oprocentowanie kredytu nie może przekraczać wartości wewnętrznej stopy zwrotu. Wreszcie obliczoną wartość wewnętrznej stopy zwrotu z inwestycji w kształcenie można porównać z innymi typowymi inwestycjami w celu oceny, na ile jest ona atrakcyjna.

\section{Średnie szkoły zawodowe}

Dla absolwenta szkoły średniej zawodowej (technikum) przyjęto, że czas nauki trwa cztery lata (sytuacja sprzed ostatniej reformy edukacji) i pierwszym rokiem zarobkowania jest 20. rok życia. Założono, że kariera zawodowa trwa do 65. roku życia, co oznacza również 50 okresów dyskontowania. Przez pierwsze cztery lata uczeń nie uzyskuje żadnych dochodów z pracy. Formuła zastosowana dla absolwenta średniej szkoły zawodowej ma postać:

$$
N P V s z=-\sum_{t=1}^{4} \frac{C_{t}^{s z}}{(1+r)^{t}}+\sum_{t=5}^{50} \frac{B_{t}^{s z}}{(1+r)^{t}}
$$


Strumień korzyści $-B_{t}^{s z}-$ przez pierwsze cztery lata (dla $t=1, \ldots$, 4) wynosi zero. Odzwierciedla to okres nauki. Strumieniem kosztów $-\mathrm{C}_{\mathrm{t}}^{\mathrm{sz}}$ - jest koszt alternatywny (analogicznie jak dla absolwentów zasadniczych szkół zawodowych), czyli oczekiwane korzyści uzyskiwane z pracy wykonywanej przez osoby z wykształceniem gimnazjalnym i poniżej. W uproszczeniu przyjęto, że uczeń średniej szkoły zawodowej również nie ponosi żadnych bezpośrednich (finansowych) kosztów zdobywania wykształcenia.

\section{Szkoły średnie ogólnokształcące i wyższe}

Jako punkt odniesienia dla wykonanych obliczeń postanowiono wycenić również opłacalność inwestycji w wykształcenie średnie ogólne (względem co najwyżej gimnazjalnego) oraz wyższe (dla uproszczenia I i ll stopień oraz ukończenie studiów jednolitych razem). Porównanie zmian w czasie dla tych czterech inwestycji zobrazuje zmieniające się motywacje ekonomiczne do podejmowania danego rodzaju kształcenia. Formuła dla absolwenta liceum ogólnokształcącego przyjmuje postać (założenie trzyletniej edukacji licealnej sprzed obecnej reformy, która dopiero wejdzie w życie, nie odnosi się zatem do osób, które już ukończyły szkołę):

$$
N P V s o=-\sum_{t=1}^{3} \frac{C_{t}^{s o}}{(1+r)^{t}}+\sum_{t=4}^{50} \frac{B_{t}^{s o}}{(1+r)^{t}}
$$

Dla absolwenta szkoły wyższej formuła z kolei przyjmuje następującą postać:

$$
N P V w=-\sum_{t=1}^{5} \frac{C_{t}^{w}}{(1+r)^{t}}+\sum_{t=6}^{47} \frac{B_{t}^{w}}{(1+r)^{t}}
$$

Ponieważ precyzyjne określenie wartości wykształcenia wyższego nie jest celem niniejszego opracowania oraz ze względu na to, że w danych BAEL z 2004 r. nie jest możliwe pogrupowanie wykształcenia wyższego według I i II stopnia, zdecydowano się na uproszczenie polegające na przyjęciu, że studia w Polsce trwają pięć lat. Jak wynika $z$ danych BAEL, jedynie co piąty absolwent studiów 
wyższych I stopnia nie decyduje się na kontynuowanie kształcenia, więc ewentualne błędy w szacunkach $z$ tego powodu nie powinny być duże. Istotnym czynnikiem mającym wpływ na otrzymane wyniki w odniesieniu do wykształcenia wyższego jest fakt pominięcia bezpośrednich nakładów finansowych ponoszonych w związku ze studiowaniem. Opracowanie Koszty kształcenia wyższego (Sztanderska, Grotkowska 2017) wskazuje, że mogą to być wartości niebagatelne, choć też zróżnicowane ze względu na kierunek, rodzaj uczelni i typ studiów. W niniejszej analizie założono, że strumień kosztów tworzą wyłącznie utracone oczekiwane zarobki. Warto również zauważyć, że absolwenci szkół wyższych rozpoczynają swoją karierę zawodową później i stąd okres dyskontowania jest o trzy lata krótszy. Wartość wykształcenia wyższego została policzona względem wykształcenia średniego ogólnego, a nie co najwyżej gimnazjalnego, jak w przypadku pozostałych poziomów wykształcenia. Warto wziąć to pod uwagę przy interpretacji otrzymanych wyników.

\section{Model płac i prawdopodobieństwa pracy - podstawowe wnioski}

Model rocznych zarobków netto sformułowany wcześniej został poddany estymacji metodą najmniejszych kwadratów. Uzyskane szacunki przedstawiono w tabeli 5 . Modele dla poszczególnych lat wyjaśniają od 32 do $35 \%$ zmienności zmiennej objaśnianej, co należy uznać za wynik typowy dla literatury przedmiotu.

Analizując parametry modelu, można wskazać na typowe zależności. Kobiety przeciętnie zarabiają mniej od mężczyzn i tendencja ta była mniej więcej stała w okresie 2004-2016. Premia z wykształcenia wyższego względem kategorii bazowej, czyli "gimnazjalne i poniżej", była najwyższa w 2004 r., zaś najniższa na koniec analizowanego okresu. Wykształcenie średnie zawodowe najwyższą premię względem kategorii bazowej oferowało w 2012 r. Warto zauważyć odwrócenie hierarchii polegające na tym, że z biegiem czasu absolwenci średnich szkół zawodowych otrzymywali wyższą premię niż absolwenci liceów ogólnokształcących, choć jeszcze w 2004 r. było odwrotnie. Wykształcenie zasadnicze zawodowe cechowało się premią rosnącą w latach 2004-2012 i jej spadkiem w ostatnim badanym roku. Wpływ wieku na wynagrodzenia był stabilny w czasie i wskazywał na wklęsłość funkcji wynagrodzeń względem wieku z maksimum osiąganym w przedziale 
43-46 lat. Wynagrodzenia rosły wraz ze wzrostem wielkości firmy i zależności te były dość stabilne w czasie. Pewnym fluktuacjom podlegała premia z zatrudnienia w sektorze prywatnym: nieznacznie ujemna w latach 2004 i 2012 oraz dodatnia w latach 2008 i 2016. Najwyższe zarobki osiągane były w największych miastach i tendencja ta pozostała niezmienna.

Analizując wyniki oszacowań modelu prawdopodobieństwa zatrudnienia (zamieszczone w tabeli 6), widzimy, że perspektywy znalezienia pracy przez kobiety były niższe niż w przypadku mężczyzn. Im wyższe wykształcenie, tym wyższa zatrudnialność. Warto zwrócić uwagę na dość istotną różnicę między wykształceniem średnim zawodowym i ogólnym na korzyść tego pierwszego. Jak sugeruje analiza modelu wynagrodzeń, różnice w płacach między osobami przyporządkowanymi na podstawie posiadanego wykształcenia do tych dwóch grup nie były duże, jednak różnice w prawdopodobieństwie uzyskania pracy już tak. Mogło to istotnie wpływać na wartość inwestycji w kształcenie. Należy jednak pamiętać, że zdobycie wykształcenia średniego zawodowego wymaga poświęcenia dodatkowego roku, co oznacza wyższą wartość kosztów alternatywnych. Osoby samotne cechowały się niższym prawdopodobieństwem znalezienia pracy niż pozostałe. Aż do 2012 r. najwyższą zatrudnialnością cechowała się grupa mieszkańców największych miast oraz wsi. W 2016 r. było to prawdą już tylko w odniesieniu do mieszkańców największych miast.

Na podstawie obu modeli wygenerowano profile płacowe oraz profile wskaźnika zatrudnienia w cyklu życia dla osób o różnych poziomach wykształcenia. Obrazują je wykresy 1 i 2. 
Wykres 1. Profile rocznych zarobków netto w cyklu życia według poziomu wykształcenia, 2004-2016

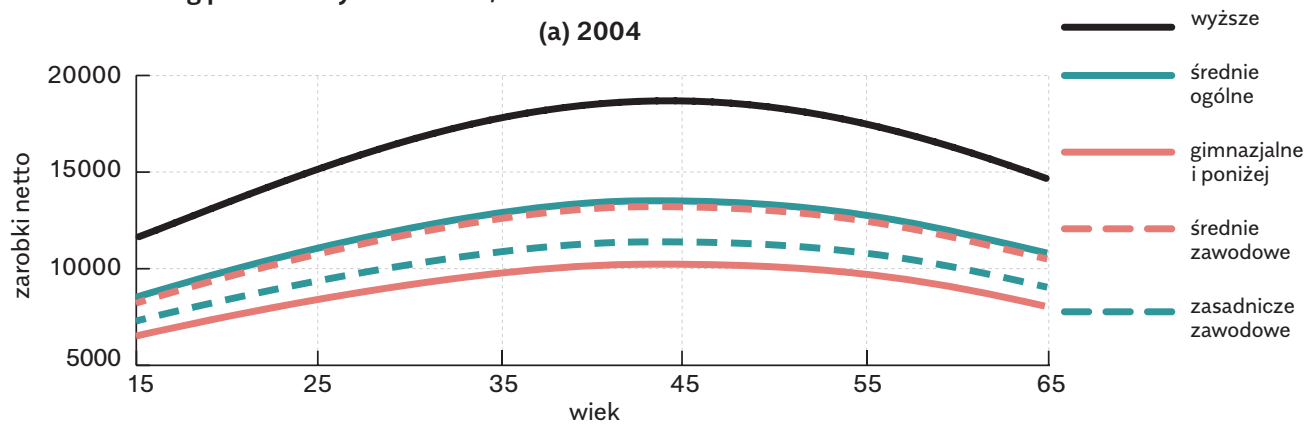

(b) 2008

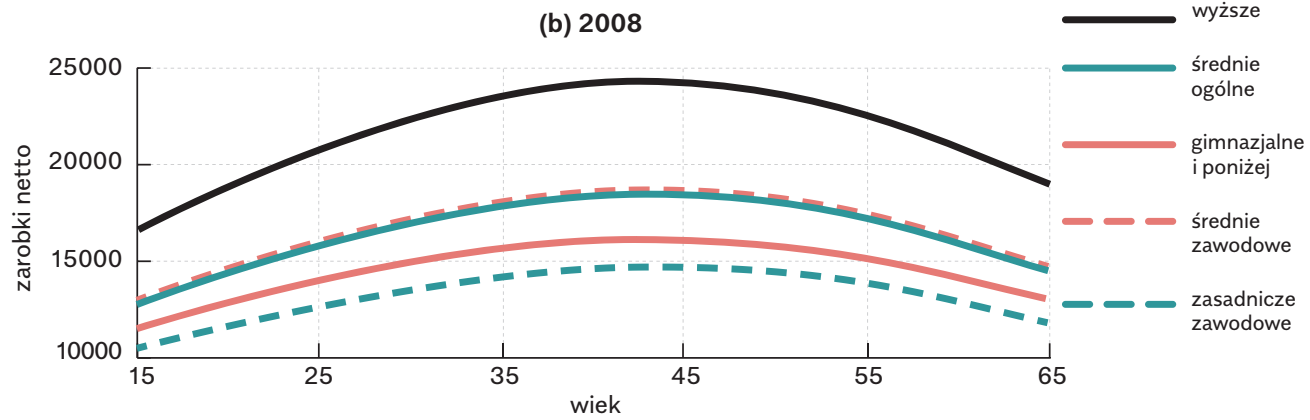

wyższe

(c) 2012

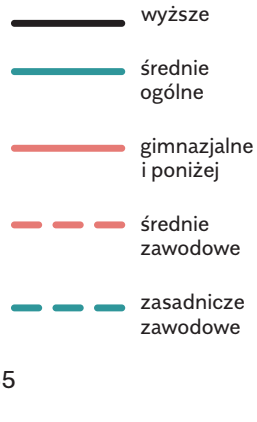

(d) 2016

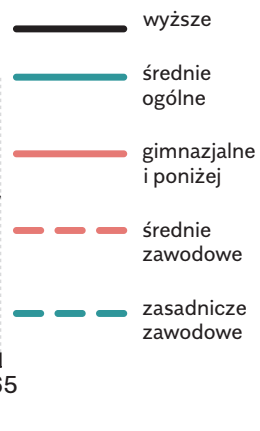

Źródło: opracowanie własne na podstawie danych BAEL, 2004-2016. 
W analizie profilów płac warto zwrócić uwagę na widoczny trend, wzmiankowany już wcześniej przy okazji analizy parametrów oszacowań modeli. W okresie między 2004 a 2016 r. rozkład płac w cyklu życia dla osób z wykształceniem średnim zawodowym przesunął się minimalnie do góry względem analogicznego rozkładu dla osób z wykształceniem średnim ogólnym.

Analiza profili wskaźników zatrudnienia ujawnia również ciekawe prawidłowości. Na przestrzeni lat 2004-2016 wyraźnie rosło prawdopodobieństwo zdobycia pracy w starszych kohortach (stopa zatrudnienia osób w wieku powyżej 50 lat). Ujmując tę kwestię nieco inaczej, można stwierdzić, że obecnie zatrudnialność spada wraz z wiekiem wolniej niż jeszcze 14 lat temu. Zatrudnialność osób z wykształceniem średnim zawodowym była wyższa niż osób z wykształceniem średnim ogólnym i tendencja ta umocniła się $w$ badanym okresie. $Z$ biegiem czasu uwidocznił się również wzrost i zbliżanie się tendencji dotyczących prawdopodobieństwa zatrudnienia dla osób z wykształceniem zasadniczym zawodowym do osób z wykształceniem średnim. Na przestrzeni lat 2004-2016 widać również zmniejszającą się lukę w stopie zatrudnienia między osobami z wykształceniem wyższym a średnim. Spadła natomiast zatrudnialność osób z wykształceniem gimnazjalnym i niższym. 
Wykres 2. Profile stopy zatrudnienia w cyklu życia według poziomu wykształcenia, 2004-2016
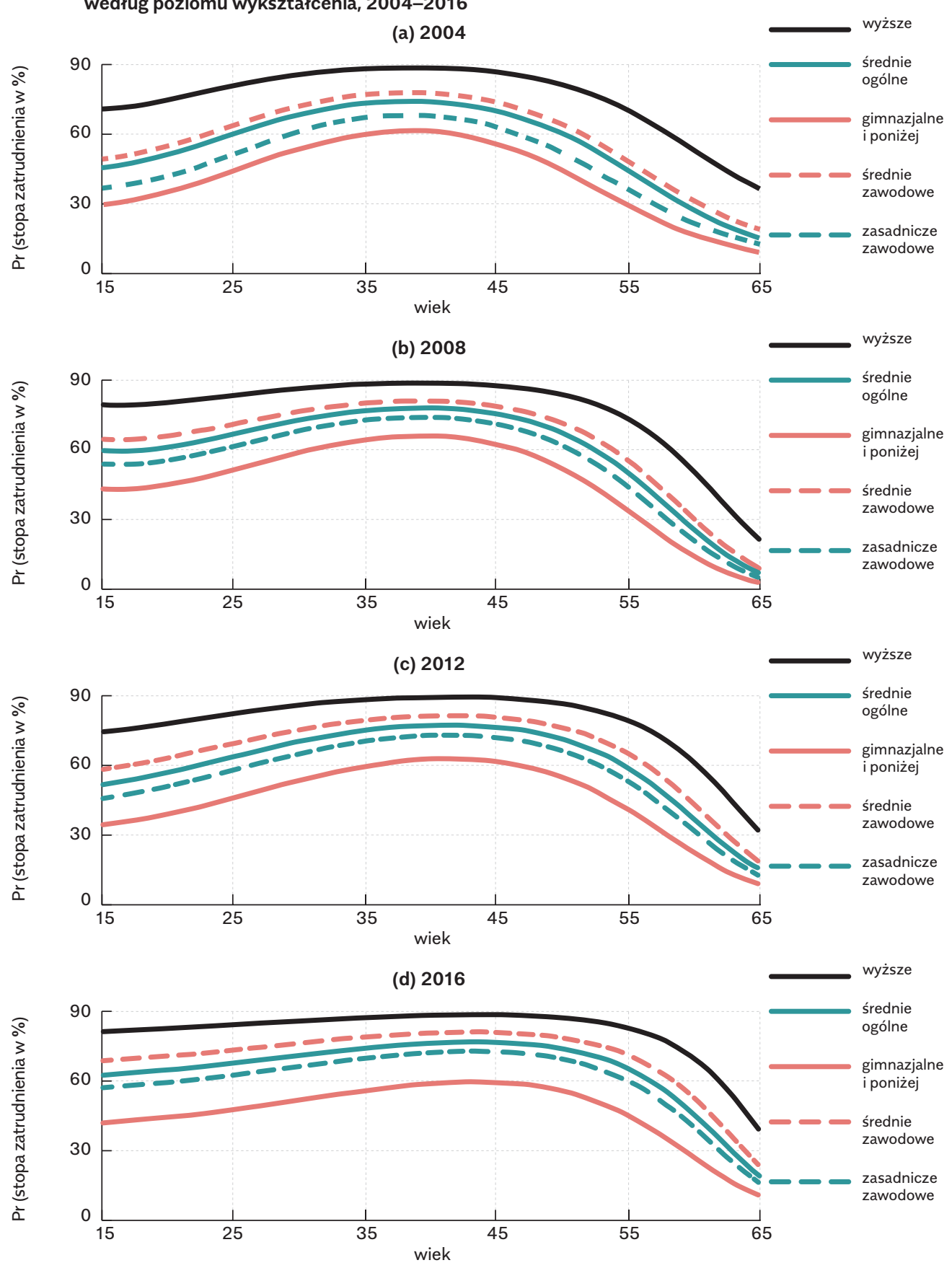

Źródło: opracowanie własne na podstawie danych BAEL, 2004-2016. 


\section{Wartość wyksztalcenia zawodowego}

\section{Populacja ogółem}

W tabeli 1 zawarto wartości bieżące oczekiwanego strumienia dochodów netto w cyklu życia według poziomu wykształcenia. Przyjęto, jak zaznaczono wcześniej, że stopa dyskontowa wynosi 3\%. Obliczone wielkości nominalne zostały urealnione wskaźnikiem cen konsumpcyjnych. We wszystkich analizowanych latach największą wartość bieżącą oczekiwanych dochodów generują absolwenci szkół wyższych. Osoby z wykształceniem średnim zawodowym osiągnęły między $57 \%$ w 2004 r. a 66\% tej wartości w 2016 r., zaś absolwenci zasadniczych szkół zawodowych między 39\% w 2004 r. a 48\% w 2016 r. Od razu nasuwa się obserwacja o względnie rosnącym potencjale zarobkowania absolwentów szkół zawodowych. Jeszcze lepiej obrazują to liczby zawarte w dwóch ostatnich wierszach tabeli 1. Między 2004 a 2016 r. zdyskontowana wartość strumienia oczekiwanych zarobków absolwentów szkół wyższych wzrosła o 52,6\%, co daje przeciętny roczny wzrost o 3,59\%. Absolwenci średnich szkół zawodowych w analogicznym okresie doświadczyli skumulowanego wzrostu wartości zdyskontowanych oczekiwanych zarobków o niemal 80\%, zaś wzrost analogicznej wartości dla absolwentów zasadniczych szkół zawodowych wyniósł aż prawie $90 \%$. Przekładając te wartości na średnie roczne tempo wzrostu, uzyskujemy 4,93\% dla absolwentów średnich szkół zawodowych i aż 5,47\% dla absolwentów zasadniczych szkół zawodowych. Bazując na tych obserwacjach, można uznać, że wartość kształcenia zawodowego w Polsce w relacji do kształcenia ogólnego oraz wyższego raczej wzrosła, aczkolwiek ukończenie średniej szkoły ogólnokształcącej przez cały okres zapewniało wyższą bieżącą wartość oczekiwanych dochodów niż ukończenie zasadniczej szkoły zawodowej. 
Tabela 1. Wartość bieżąca strumienia oczekiwanych dochodów netto

w cyklu życia według poziomu wykształcenia, $r=3 \%$

\begin{tabular}{l|c|c|c|c|c} 
rok & wyższe & $\begin{array}{c}\text { średnie } \\
\text { ogólne }\end{array}$ & $\begin{array}{c}\text { średnie } \\
\text { zawodowe }\end{array}$ & $\begin{array}{c}\text { zasadnicze } \\
\text { zawodowe }\end{array}$ & $\begin{array}{c}\text { gimnazjalne } \\
\text { i poniżej }\end{array}$ \\
\hline 2004 & 422603,00 & 228175,70 & 239932,60 & 164956,25 & 124476,02 \\
\hline 2008 & 525211,00 & 315005,28 & 337939,26 & 251738,17 & 189203,91 \\
\hline 2012 & 605878,39 & 339773,69 & 376903,88 & 270185,33 & 186000,13 \\
\hline 2016 & 645079,93 & 385189,47 & 427470,48 & 312420,70 & 212616,51 \\
\hline $\begin{array}{l}\text { wzrost skumulowany } \\
2016 / 2004 \text { (w \%) }\end{array}$ & 52,64 & 68,81 & 78,16 & 89,40 & 70,81 \\
\hline $\begin{array}{l}\text { średnioroczny wzrost } \\
2004-2016 \text { (w \%) }\end{array}$ & 3,59 & 4,46 & 4,93 & 5,47 & 4,56
\end{tabular}

Źródło: obliczenia własne na podstawie danych BAEL, 2004-2016.

W tabeli 2 przedstawiono obliczenia wartości bieżącej netto (uwzględniającej koszty i różne okresy dyskontowania) oraz wewnętrznej stopy zwrotu dla poszczególnych poziomów wykształcenia. Dodatkowo dla lepszego zobrazowania osiągniętych rezultatów wartości wewnętrznej stopy zwrotu przedstawiono na wykresie 3. $\mathrm{Na}$ podstawie obliczeń można stwierdzić, że wykształcenie zawodowe w Polsce jest dość atrakcyjne. Przy porównywaniu obliczonych wartości wykształcenia warto pamiętać, że punktem odniesienia dla wykształcenia średniego i zasadniczego zawodowego jest wykształcenie co najwyżej gimnazjalne, dla wykształcenia wyższego jako punkt odniesienia przyjęto zaś wykształcenie średnie ogólne (jako najbardziej typową ścieżkę kształcenia). Zdobycie wykształcenia zawodowego dawało w latach 2004-2016 coraz wyższą stopę zwrotu. W przypadku wykształcenia średniego zawodowego przyrost tej wartości może nie jest spektakularny, za to jest stabilny w czasie. W 2004 r. stopa zwrotu z tego typu wykształcenia wyniosła $11,43 \%$, zaś w 2016 r. było to już $13,18 \%$. Imponująco przedstawia się natomiast dynamika wewnętrznej stopy zwrotu dla wykształcenia zasadniczego zawodowego, której wartość wzrosła między 2004 a 2016 r. o ponad 3 pkt. proc. - z 5,61\% do $9,04 \%$. Podczas analizy zmian w czasie można zauważyć, że stopa zwrotu z wykształcenia wyższego podlegała pewnym wahaniom i jednak nieznacznie zmniejszyła się między 2004 a 2016 r. Wykształcenie 
średnie ogólne, choć na przestrzeni lat 2004-2016 zyskujące na atrakcyjności w niewielkim stopniu, dawało jednak istotnie większą stopę zwrotu niż wykształcenie średnie zawodowe i zasadnicze zawodowe. Może to tłumaczyć dużą chęć do podejmowania tego typu kształcenia, nawet w wypadku decyzji o zaprzestaniu edukacji na tym etapie.

Porównując dane o wartości bieżącej strumienia dochodów w cyklu życia z danymi o wewnętrznej stopie zwrotu, można zaryzykować stwierdzenie, że powstałe na początku transformacji znaczne dysproporcje w zarobkach na niekorzyść osób z wykształceniem zawodowym ulegają powolnej i stopniowej redukcji po 2004 r. Czynnikami, które mogłyby hipotetycznie tłumaczyć tę tendencję, mogą być zmiany technologiczne (zmiany w strukturze popytu na pracę), a także migracje zarobkowe i wynikający z nich znaczący ubytek podaży siły roboczej o kwalifikacjach zawodowych w związku z liberalizacją dostępu do rynków pracy Unii Europejskiej. Weryfikacja takiej hipotezy wymagałaby, rzecz jasna, dodatkowych badań.

Tabela 2. Wartość bieżąca netto i wewnętrzna stopa zwrotu

według poziomu wykształcenia, 2004-2016

\begin{tabular}{l|l|c|c|c|c}
\multirow{2}{*}{ rok } & \multirow{2}{*}{ miara } & \multicolumn{4}{|c}{ wykształcenie } \\
\cline { 3 - 6 } & & wyższe & średnie ogólne & średnie zawodowe & zasadnicze zawodowe \\
\hline \multirow{2}{*}{2004} & NPV & 87796,71 & 56022,52 & 55490,64 & 10007,63 \\
\cline { 2 - 6 } & IRR $(w \%)$ & 10,68 & 13,78 & 11,43 & 5,61 \\
\hline \multirow{2}{*}{2008} & NPV & 99744,41 & 73033,35 & 78969,09 & 22315,09 \\
\cline { 2 - 6 } & IRR (w \%) & 9,57 & 13,35 & 11,55 & 6,89 \\
\hline \multirow{2}{*}{2012} & NPV & 152353,50 & 105438,37 & 122898,93 & 41365,57 \\
\cline { 2 - 6 } & IRR (w \%) & 10,65 & 14,28 & 12,99 & 8,34 \\
\hline \multirow{2}{*}{2016} & NPV & 144645,40 & 119909,79 & 140631,82 & 53316,05 \\
\cline { 2 - 6 } & IRR (w \%) & 9,86 & 14,59 & 13,18 & 9,04
\end{tabular}

*Wartości bieżące netto zostały obliczone w cenach bieżących, przy stopie dyskontowej 3\%.

Punktem odniesienia dla wykształcenia średniego i zasadniczego zawodowego jest wykształcenie co najwyżej gimnazjalne, zaś dla wykształcenia wyższego wykształcenie średnie ogólne (najbardziej typowa ścieżka kształcenia prowadząca do uzyskania wykształcenia wyższego). 
Wykres 3. Wewnętrzna stopa zwrotu z inwestycji w kształcenie według poziomu wykształcenia, 2004-2016 (w \%)

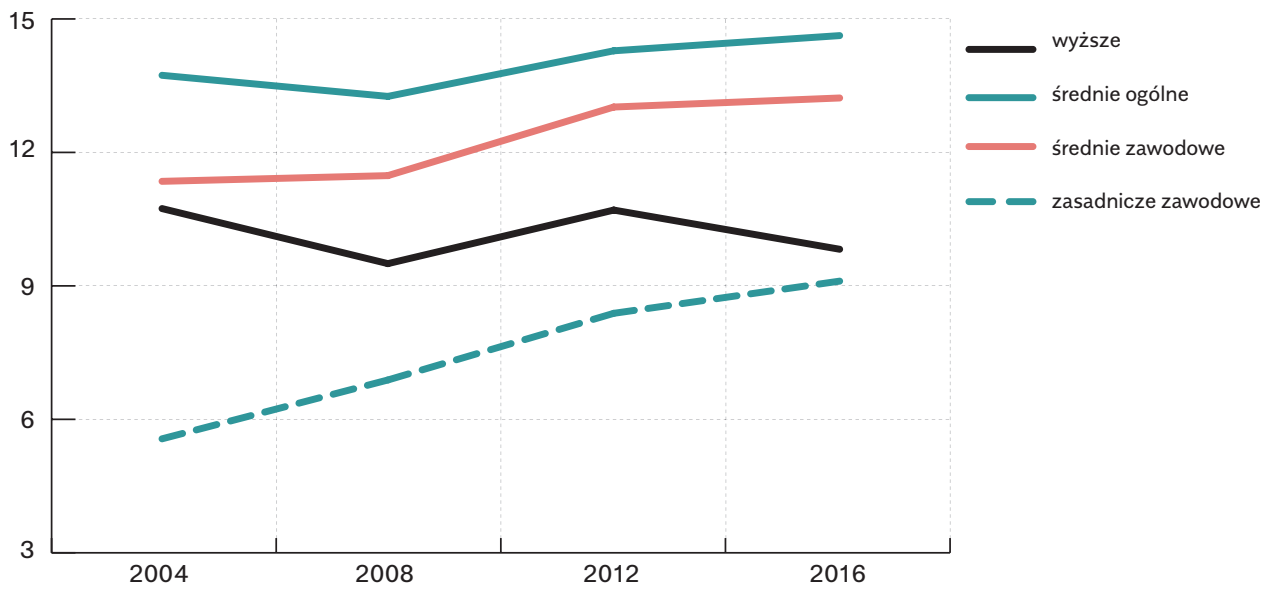

Źródło: opracowanie własne na podstawie danych BAEL, 2004-2016.

Różnice w stopach zwrotu i wartości wykształcenia według płci

Analogiczne obliczenia jak dla populacji ogółem wykonano również osobno dla kobiet i mężczyzn, szacując dla każdej grupy oddzielne modele wynagrodzeń i prawdopodobieństwo zatrudnienia z wykorzystaniem tych samych zmiennych objaśniających. W obliczeniach wewnętrznej stopy zwrotu i wartości bieżącej netto strumieni dochodów przyjęto, że horyzont dyskontowania dla mężczyzn kończy się w 65 . roku życia, dla kobiet zaś w 60 . Tabela 3 zawiera zestawienie wartości bieżących oczekiwanego strumienia dochodów netto w cyklu życia według poziomu wykształcenia, osobno dla kobiet i dla mężczyzn. Wartości przeliczono w cenach z $2016 \mathrm{r}$. 
Tabela 3. Wartość bieżąca strumienia oczekiwanych dochodów netto

w cyklu życia według płci i poziomu wykształcenia, $r=3 \%$

\begin{tabular}{|c|c|c|c|c|c|}
\hline rok & wyższe & $\begin{array}{l}\text { średnie } \\
\text { ogólne }\end{array}$ & $\begin{array}{c}\text { średnie } \\
\text { zawodowe }\end{array}$ & $\begin{array}{l}\text { zasadnicze } \\
\text { zawodowe }\end{array}$ & $\begin{array}{l}\text { gimnazjalne } \\
\text { i poniżej }\end{array}$ \\
\hline \multicolumn{6}{|c|}{ kobiety } \\
\hline 2004 & 341529,83 & 161841,63 & 176891,32 & 108231,59 & 81799,56 \\
\hline 2008 & 423638,48 & 224151,17 & 245063,73 & 158679,88 & 115727,41 \\
\hline 2012 & 486416,64 & 230236,20 & 268794,79 & 168532,14 & 112876,64 \\
\hline 2016 & 513478,78 & 266770,70 & 314032,45 & 199745,40 & 127786,66 \\
\hline $\begin{array}{l}\text { wzrost skumulowany } \\
2016 / 2004 \text { (w \%) }\end{array}$ & 50,35 & 64,83 & 77,53 & 84,55 & 56,22 \\
\hline $\begin{array}{l}\text { średnioroczny wzrost } \\
\text { 2004-2016 (w \%) }\end{array}$ & 3,46 & 4,25 & 4,90 & 5,24 & 3,79 \\
\hline \multicolumn{6}{|c|}{ mężczyźni } \\
\hline 2004 & 480245,90 & 293898,74 & 300404,27 & 228059,38 & 173208,56 \\
\hline 2008 & 594539,47 & 399421,97 & 429109,94 & 355013,71 & 283077,51 \\
\hline 2012 & 689182,44 & 456158,50 & 482128,21 & 383685,62 & 280619,68 \\
\hline 2016 & 753386,77 & 517916,84 & 542405,79 & 444391,46 & 328596,49 \\
\hline $\begin{array}{l}\text { wzrost skumulowany } \\
2016 / 2004 \text { (w \%) }\end{array}$ & 56,88 & 76,22 & 80,56 & 94,86 & 89,71 \\
\hline $\begin{array}{l}\text { średnioroczny wzrost } \\
2004-2016 \text { (w \%) }\end{array}$ & 3,82 & 4,83 & 5,05 & 5,72 & 5,48 \\
\hline
\end{tabular}

Źródło: opracowanie własne na podstawie danych BAEL, 2004-2016.

Wartość bieżąca strumienia oczekiwanych dochodów w cyklu życia zawodowego jest wyraźnie większa w przypadku mężczyzn i dotyczy to wszystkich poziomów wykształcenia i wszystkich obserwowanych okresów. Po części wynika to z na ogół dłuższego okresu zarobkowania mężczyzn (tu założono arbitralnie 60 lat jako koniec kariery zawodowej dla kobiet i 65 lat dla mężczyzn), częściowo z wyższego prawdopodobieństwa ich zatrudnienia i, wreszcie, z premii płacowej uzyskiwanej przez mężczyzn, niedającej się wyjaśnić cechami obserwowalnymi.

Szczególnie interesujące jest porównanie wartości bieżącej oczekiwanych zarobków najsłabiej wykształconych mężczyzn i kobiet, którzy stanowią grupę referencyjną dla osób z wykształceniem zawodowym. O ile w przypadku kobiet wartość ta wzrosła w ujęciu skumulowanym między 2004 a 2016 r. o ok. 56\%, to w przypadku mężczyzn wzrost 
ten wyniósł aż prawie $90 \%$. Ma to istotne konsekwencje dla wartości wykształcenia, motywacji do jego podejmowania i stopy zwrotu. Nietrudno też zauważyć, że różnica między bieżącą wartością strumienia oczekiwanych dochodów netto kobiet w stosunku do tej samej wartości dla mężczyzn jest najmniejsza dla wykształcenia wyższego. Może to wskazywać, że stosunkowo najkorzystniejszym wyborem edukacyjnym dla kobiet było podejmowanie studiów wyższych. Jeśli zaś kobiety chciałyby zakończyć edukację na poziomie szkoły ponadgimnazjalnej, to najbardziej uzasadnione wydawałoby się kształcenie w średniej szkole zawodowej (technikum). Mężczyźni oczywiście też zyskiwali, kończąc studia albo gdy ich nie podejmowali, zdobywając średnie wykształcenie zawodowe. Z tym że ich przewaga zarobkowa nad kobietami w obu tych przypadkach była mniejsza niż wówczas, kiedy skończyliby inne szkoły ponadgimnazjalne i po nich podjęli pracę zawodową.

Tabela 4 zawiera porównanie wartości bieżącej netto oraz wewnętrznej stopy zwrotu dla kobiet i mężczyzn. Porównanie to ujawnia, że mężczyźni osiągali wyższe stopy zwrotu z kształcenia jedynie w przypadku wykształcenia zasadniczego zawodowego, przy czym dysproporcja ta w okresie 2004-2016 zmalała znacząco. O ile jeszcze w 2004 r. stopa zwrotu dla mężczyzn z tym poziomem wykształcenia była niemal dwukrotnie wyższa niż dla kobiet, to w 2016 r. obie te wartości niemal zrównały się ze sobą. Potwierdza się wysoka atrakcyjność wykształcenia średniego ogólnokształcącego i zawodowego dla obu płci, przy czym jest ona wyższa dla kobiet. Porównanie stóp zwrotu dla wykształcenia wyższego ujawnia jeszcze bardziej znaczącą przewagę zyskowności takiej inwestycji dla kobiet i może tłumaczyć ich większą motywację do kontynuowania kształcenia na tym poziomie. Wykształcenie wyższe przy tym generowało $w$ całym badanym okresie dość stabilną stopę zwrotu dla kobiet. W przypadku mężczyzn obserwujemy zaś jej wyraźny spadek, widoczny zwłaszcza w 2008 r. Hipotezą wymagającą dalszych badań pozostaje, na ile mogło mieć to związek z odmienną strukturą zatrudnienia kobiet i mężczyzn według sektora własności w powiązaniu z koniunkturą gospodarczą w okresie kryzysu finansowego. 
Tabela 4. Wartość bieżąca netto i wewnętrzna stopa zwrotu według płci i poziomu wykształcenia, 2004-2016

\begin{tabular}{|c|c|c|c|c|c|}
\hline \multirow[b]{2}{*}{ rok } & \multirow[b]{2}{*}{ miara } & \multicolumn{4}{|c|}{ wykształcenie } \\
\hline & & wyższe & średnie ogólne & średnie zawodowe & $\begin{array}{l}\text { zasadnicze } \\
\text { zawodowe }\end{array}$ \\
\hline \multicolumn{6}{|c|}{ kobiety } \\
\hline \multirow{2}{*}{2004} & NPV & 80171,00 & 41355,60 & 44505,30 & 2073,91 \\
\hline & IRR (w \%) & 11,50 & 12,42 & 11,04 & 3,71 \\
\hline \multirow{2}{*}{2008} & NPV & 95893,55 & 65730,64 & 72054,47 & 13219,34 \\
\hline & IRR (w \%) & 10,84 & 14,31 & 12,66 & 6,08 \\
\hline \multirow{2}{*}{2012} & NPV & 151841,97 & 81648,83 & 103670,22 & 24616,40 \\
\hline & IRR (w \%) & 12,41 & 13,61 & 13,27 & 7,14 \\
\hline \multirow{2}{*}{2016} & NPV & 140938,82 & 97141,08 & 124989,72 & 35848,87 \\
\hline & IRR (w \%) & 11,33 & 14,20 & 13,77 & 8,04 \\
\hline \multicolumn{6}{|c|}{ mężczyźni } \\
\hline \multirow{2}{*}{2004} & NPV & 78694,41 & 62934,71 & 57186,91 & 15100,65 \\
\hline & IRR (w \%) & 9,30 & 13,89 & 10,76 & 6,33 \\
\hline \multirow{2}{*}{2008} & NPV & 82587,63 & 55962,61 & 65335,26 & 20485,05 \\
\hline & IRR (w \%) & 7,91 & 10,08 & 9,11 & 5,95 \\
\hline \multirow{2}{*}{2012} & NPV & 112905,95 & 112597,40 & 116388,41 & 45916,75 \\
\hline & IRR (w \%) & 8,12 & 13,50 & 11,20 & 8,00 \\
\hline \multirow{2}{*}{2016} & NPV & 110223,42 & 120976,38 & 122290,01 & 53732,54 \\
\hline & IRR (w \%) & 7,62 & 13,09 & 10,68 & 8,09 \\
\hline
\end{tabular}

* Wartości bieżące netto zostały obliczone w cenach bieżących, przy stopie dyskontowej 3\%.

Punktem odniesienia dla wykształcenia średniego i zasadniczego zawodowego jest wykształcenie co najwyżej gimnazjalne, zaś dla wykształcenia wyższego wykształcenie średnie ogólne (najbardziej typowa ścieżka kształcenia prowadząca do uzyskania wykształcenia wyższego).

Źródło: opracowanie własne na podstawie danych BAEL, 2004-2016. 
Tabela 5. Oszacowania modelu wynagrodzeń

\begin{tabular}{|c|c|c|c|c|}
\hline & 2004 & 2008 & 2012 & 2016 \\
\hline \multirow{2}{*}{ płeć: kobieta } & $-0,2725^{\star \star *}$ & $-0,3002^{\star \star \star}$ & $-0,2920^{\star \star *}$ & $-0,2765^{\star \star \star}$ \\
\hline & {$[0,0044]$} & {$[0,0036]$} & {$[0,0028]$} & {$[0,0042]$} \\
\hline \multirow{2}{*}{ wykształcenie: wyższe } & $0,6300^{\star \star \star}$ & $0,5847^{\star \star \star}$ & $0,6210^{\star \star \star}$ & $0,5452^{\star \star \star}$ \\
\hline & {$[0,0091]$} & {$[0,0077]$} & {$[0,0061]$} & {$[0,0098]$} \\
\hline \multirow{2}{*}{ średnie zawodowe } & $0,2846^{\star \star \star}$ & $0,2785^{\star \star \star}$ & $0,2961^{\star * *}$ & $0,2610^{* * *}$ \\
\hline & {$[0,0082]$} & {$[0,0072]$} & {$[0,0058]$} & {$[0,0095]$} \\
\hline \multirow{2}{*}{ średnie ogólne } & $0,2923^{\star \star \star}$ & $0,2652^{\star \star \star}$ & $0,2764^{\star \star \star}$ & $0,2365^{\star \star \star}$ \\
\hline & {$[0,0109]$} & {$[0,0091]$} & {$[0,0071]$} & {$[0,0113]$} \\
\hline \multirow{2}{*}{ zasadnicze zawodowe } & $0,1128^{\star \star \star}$ & $0,1151^{\star \star \star}$ & $0,1312^{\star \star \star}$ & $0,1030^{\star * *}$ \\
\hline & {$[0,0080]$} & {$[0,0070]$} & {$[0,0058]$} & {$[0,0094]$} \\
\hline \multirow{2}{*}{ wiek } & $0,0561^{\star \star \star}$ & $0,0520^{\star \star *}$ & $0,0559^{\star \star \star *}$ & $0,0527^{\star \star *}$ \\
\hline & {$[0,0015]$} & {$[0,0013]$} & {$[0,0009]$} & {$[0,0013]$} \\
\hline \multirow{2}{*}{ wiek 2} & $-0,0006^{\star \star *}$ & $-0,0006^{\star \star \star}$ & $-0,0006^{\star \star \star}$ & $-0,0006^{\star \star \star}$ \\
\hline & {$[0,0000]$} & {$[0,0000]$} & {$[0,0000]$} & {$[0,0000]$} \\
\hline \multirow{2}{*}{ kujawsko-pomorskie } & $-0,0564^{\star \star *}$ & $-0,0654^{\star * *}$ & $-0,0782^{\text {** }}$ & $-0,0947^{\star \star \star}$ \\
\hline & {$[0,0112]$} & {$[0,0103]$} & {$[0,0078]$} & {$[0,0121]$} \\
\hline \multirow{2}{*}{ lubelskie } & $-0,0821^{\text {***}}$ & $-0,0994^{\star \star \star}$ & $-0,1101^{\star \star \star}$ & $-0,1511^{\star \star \star}$ \\
\hline & {$[0,0109]$} & {$[0,0098]$} & {$[0,0075]$} & {$[0,0117]$} \\
\hline \multirow{2}{*}{ lubuskie } & $-0,0356^{* *}$ & $-0,0188$ & $-0,0398^{* * *}$ & $-0,0413^{* * *}$ \\
\hline & {$[0,0118]$} & {$[0,0101]$} & {$[0,0077]$} & {$[0,0121]$} \\
\hline \multirow{2}{*}{ łódzkie } & $-0,0166$ & $-0,0391^{\star * *}$ & $-0,0607^{\star \star *}$ & $-0,0914^{\star * *}$ \\
\hline & {$[0,0114]$} & {$[0,0092]$} & {$[0,0076]$} & {$[0,0137]$} \\
\hline \multirow{2}{*}{ małopolskie } & 0,0016 & $-0,0193^{*}$ & $-0,0227^{\star *}$ & $-0,0231$ \\
\hline & {$[0,0117]$} & {$[0,0097]$} & {$[0,0077]$} & {$[0,0129]$} \\
\hline \multirow{2}{*}{ mazowieckie } & $0,1147^{\star \star \star}$ & $0,0923^{\star \star \star}$ & $0,0776^{\star \star \star}$ & $0,0313^{\star *}$ \\
\hline & {$[0,0109]$} & {$[0,0087]$} & {$[0,0069]$} & {$[0,0108]$} \\
\hline \multirow{2}{*}{ opolskie } & $-0,0265^{\star}$ & $0,0201^{*}$ & $-0,0046$ & $-0,0275^{\star}$ \\
\hline & {$[0,0134]$} & {$[0,0099]$} & {$[0,0075]$} & {$[0,0128]$} \\
\hline \multirow{2}{*}{ podkarpackie } & $-0,0176$ & $-0,1323^{\text {***}}$ & $-0,1335^{\star \star \star}$ & $-0,1404^{\star \star \star *}$ \\
\hline & {$[0,0113]$} & {$[0,0097]$} & {$[0,0078]$} & {$[0,0128]$} \\
\hline \multirow{2}{*}{ podlaskie } & $-0,0643^{\star \star *}$ & $-0,0510^{\star \star * *}$ & $-0,0919^{* \star *}$ & $-0,1233^{\star \star \star}$ \\
\hline & {$[0,0125]$} & {$[0,0103]$} & {$[0,0076]$} & {$[0,0118]$} \\
\hline \multirow{2}{*}{ pomorskie } & $-0,0124$ & $0,0608^{\star \star \star}$ & $-0,0021$ & $0,0233^{*}$ \\
\hline & {$[0,0115]$} & {$[0,0096]$} & {$[0,0073]$} & {$[0,0115]$} \\
\hline \multirow{2}{*}{ śląskie } & 0,0132 & $-0,0410^{\star \star *}$ & $-0,0307^{\star \star \star}$ & $-0,0724^{\star \star \star}$ \\
\hline & {$[0,0106]$} & {$[0,0088]$} & {$[0,0070]$} & {$[0,0116]$} \\
\hline
\end{tabular}




\begin{tabular}{|c|c|c|c|c|}
\hline \multirow{2}{*}{ świętokrzyskie } & $-0,0710^{\star \star \star}$ & $-0,1263^{\star \star \star}$ & $-0,1120^{\star \star \star}$ & $-0,1171^{\star \star \star}$ \\
\hline & {$[0,0137]$} & {$[0,0100]$} & {$[0,0077]$} & {$[0,0126]$} \\
\hline \multirow{2}{*}{ warmińsko-mazurskie } & $-0,0154$ & $-0,0125$ & $-0,0472^{\star \star \star}$ & $-0,0776^{\star \star \star}$ \\
\hline & {$[0,0113]$} & {$[0,0097]$} & {$[0,0075]$} & {$[0,0118]$} \\
\hline \multirow{2}{*}{ wielkopolskie } & 0,0079 & $-0,0262^{\star \star}$ & $-0,0236^{\star \star \star}$ & $-0,0514^{\star \star \star}$ \\
\hline & {$[0,0104]$} & {$[0,0092]$} & {$[0,0071]$} & {$[0,0125]$} \\
\hline \multirow{2}{*}{ zachodniopomorskie } & $0,0432^{\star \star \star}$ & $0,0233^{*}$ & $-0,011$ & 0,0227 \\
\hline & {$[0,0124]$} & {$[0,0102]$} & {$[0,0079]$} & {$[0,0135]$} \\
\hline \multirow{2}{*}{ wielkość firmy 11-19 } & $0,0872^{\star \star \star}$ & $0,0884^{\star \star \star}$ & $0,0951^{\star \star \star}$ & $0,0986^{\star \star \star}$ \\
\hline & {$[0,0072]$} & {$[0,0059]$} & {$[0,0044]$} & {$[0,0068]$} \\
\hline \multirow{2}{*}{ wielkość firmy 20-49 } & $0,1068^{\star \star *}$ & $0,1218^{\star \star \star}$ & $0,1344^{\star \star \star}$ & $0,1529^{\star \star \star}$ \\
\hline & {$[0,0072]$} & {$[0,0060]$} & {$[0,0045]$} & {$[0,0069]$} \\
\hline \multirow{2}{*}{ wielkość firmy 101-250 } & $0,2103^{\star \star \star}$ & $0,1963^{\star \star \star}$ & $0,1943^{\star \star \star}$ & $0,2119^{\star \star \star}$ \\
\hline & {$[0,0061]$} & {$[0,0053]$} & {$[0,0042]$} & {$[0,0063]$} \\
\hline \multirow{2}{*}{ wielkość firmy > 251} & & $0,3302^{\star * *}$ & $0,3166^{\star \star \star}$ & $0,3191^{\star \star *}$ \\
\hline & & {$[0,0066]$} & {$[0,0045]$} & {$[0,0066]$} \\
\hline \multirow{2}{*}{ sektor: prywatny } & $-0,0172^{\star \star \star}$ & $0,0217^{\star * \star}$ & $-0,0097^{\star \star}$ & $0,0230^{\star \star \star}$ \\
\hline & {$[0,0049]$} & {$[0,0041]$} & {$[0,0032]$} & {$[0,0049]$} \\
\hline \multirow{2}{*}{ miasto $50-100$ tys. } & $-0,0447^{\star \star \star}$ & $-0,0767^{\star \star \star *}$ & $-0,0574^{\star \star \star *}$ & $-0,0225^{\star \star}$ \\
\hline & {$[0,0081]$} & {$[0,0069]$} & {$[0,0053]$} & {$[0,0075]$} \\
\hline \multirow{2}{*}{ miasto $20-50$ tys. } & $-0,0601^{\star \star \star}$ & $-0,0558^{\star \star \star}$ & $-0,0653^{\star \star \star}$ & $-0,0699^{* * *}$ \\
\hline & {$[0,0075]$} & {$[0,0061]$} & {$[0,0046]$} & {$[0,0072]$} \\
\hline \multirow{2}{*}{ miasto $10-20$ tys. } & $-0,0656^{\star \star \star}$ & $-0,0623^{\star \star \star}$ & $-0,0723^{\star \star \star}$ & $-0,0406^{\star \star *}$ \\
\hline & {$[0,0083]$} & {$[0,0071]$} & {$[0,0054]$} & {$[0,0082]$} \\
\hline \multirow{2}{*}{ miasto 5-10 tys. } & $-0,0562^{\star \star \star}$ & $-0,0782^{\star \star \star}$ & $-0,0668^{* * *}$ & $-0,0652^{\star \star *}$ \\
\hline & {$[0,0117]$} & {$[0,0093]$} & {$[0,0073]$} & {$[0,0124]$} \\
\hline \multirow{2}{*}{ miasto $2-5$ tys. } & $-0,0877^{\star \star \star}$ & $-0,0768^{\star \star \star}$ & $-0,0562^{\star \star \star}$ & $-0,0557^{\star \star \star}$ \\
\hline & {$[0,0139]$} & {$[0,0112]$} & {$[0,0090]$} & {$[0,0147]$} \\
\hline \multirow{2}{*}{ miasto $<2$ tys. } & $-0,1158^{\star \star}$ & $-0,1088^{\star *}$ & $-0,0457$ & $-0,0700^{\star}$ \\
\hline & {$[0,0371]$} & {$[0,0343]$} & {$[0,0282]$} & {$[0,0336]$} \\
\hline \multirow{2}{*}{ wieś } & $-0,0762^{\star \star \star}$ & $-0,0774^{\star \star \star}$ & $-0,0639^{* \star *}$ & $-0,0484^{\star \star *}$ \\
\hline & {$[0,0059]$} & {$[0,0047]$} & {$[0,0036]$} & {$[0,0054]$} \\
\hline \multirow{2}{*}{ stała } & $8,0094^{\star \star \star}$ & $8,4390 * * *$ & $8,5845^{\star * \star}$ & $8,7105^{\star * *}$ \\
\hline & {$[0,0310]$} & {$[0,0269]$} & {$[0,0196]$} & {$[0,0301]$} \\
\hline dopasowane R2 & 0,3211 & 0,335 & 0,3549 & 0,3322 \\
\hline$N$ & 34195 & 48419 & 86071 & 36320 \\
\hline
\end{tabular}

W nawiasach kwadratowych pod oszacowaniami parametrów podano wartości błędów

standardowych. Poziomy istotności oznaczono następująco: ${ }^{\star \star *} p<0,001$; ${ }^{\star \star} p<0,01$;

* $\mathrm{p}<0,05$

Źródło: opracowanie własne na podstawie danych BAEL, 2004-2016. 
Tabela 6. Oszacowania modelu prawdopodobieństwa zatrudnienia, iloraz szans

\begin{tabular}{|c|c|c|c|c|}
\hline & 2004 & 2008 & 2012 & 2016 \\
\hline \multirow{2}{*}{ płeć: kobieta } & $0,4760^{\text {***}}$ & $0,3587^{* \star *}$ & $0,3827^{\star \star \star}$ & $0,3558^{\star \star *}$ \\
\hline & {$[0,0063]$} & {$[0,0056]$} & {$[0,0040]$} & {$[0,0045]$} \\
\hline \multirow{2}{*}{ wykształcenie: wyższe } & $6,9504^{\star \star \star}$ & $6,6002^{\star \star \star}$ & $7,2555^{\star \star \star}$ & $9,1391^{\star \star *}$ \\
\hline & {$[0,1842]$} & {$[0,1972]$} & {$[0,1427]$} & {$[0,2159]$} \\
\hline \multirow{2}{*}{ średnie zawodowe } & $2,4901^{\star \star *}$ & $2,6467^{* * *}$ & $3,0953^{\star \star *}$ & $3,7621^{\star \star \star}$ \\
\hline & {$[0,0495]$} & {$[0,0617]$} & {$[0,0516]$} & {$[0,0785]$} \\
\hline \multirow{2}{*}{ średnie ogólne } & $2,1039^{\star \star \star}$ & $2,0846^{\star \star \star}$ & $2,2812^{\star \star \star}$ & $2,6848^{\star \star *}$ \\
\hline & {$[0,0587]$} & {$[0,0657]$} & {$[0,0490]$} & {$[0,0700]$} \\
\hline \multirow{2}{*}{ zasadnicze zawodowe } & $1,4083^{\star \star * *}$ & $1,5926^{\star \star *}$ & $1,7375^{\star \star \star *}$ & $2,0480^{\text {***}}$ \\
\hline & {$[0,0258]$} & {$[0,0346]$} & {$[0,0274]$} & {$[0,0408]$} \\
\hline \multirow{2}{*}{ wiek } & $0,5323^{\text {***}}$ & $0,5889^{* \star *}$ & $0,8209^{\star \star \star *}$ & 1,0272 \\
\hline & {$[0,0355]$} & {$[0,0595]$} & {$[0,0481]$} & {$[0,0720]$} \\
\hline \multirow{2}{*}{ wiek 2} & $1,0337^{\star \star \star}$ & $1,0250^{\star \star *}$ & $1,0106^{\star \star \star}$ & 0,9978 \\
\hline & {$[0,0026]$} & {$[0,0040]$} & {$[0,0022]$} & {$[0,0025]$} \\
\hline \multirow{2}{*}{ wiek 3} & $0,9994^{* \star *}$ & $0,9996^{\star \star *}$ & $0,9999^{\star \star \star}$ & $1,0001^{* \star}$ \\
\hline & {$[0,0000]$} & {$[0,0001]$} & {$[0,0000]$} & {$[0,0000]$} \\
\hline \multirow{2}{*}{ wiek 4} & $1,0000^{\star \star \star}$ & $1,0000^{\star \star \star}$ & 1,0000 & $1,0000^{\star \star \star}$ \\
\hline & {$[0,0000]$} & {$[0,0000]$} & {$[0,0000]$} & {$[0,0000]$} \\
\hline \multirow{2}{*}{ kujawsko-pomorskie } & $1,1331^{\star \star \star}$ & 0,9924 & 1,0014 & $0,8753^{\star \star *}$ \\
\hline & {$[0,0389]$} & {$[0,0403]$} & {$[0,0289]$} & {$[0,0302]$} \\
\hline \multirow{2}{*}{ lubelskie } & $1,6005^{\star \star \star}$ & $1,2236^{\star \star \star}$ & $1,1884^{\star \star \star}$ & $0,8715^{\star \star \star}$ \\
\hline & {$[0,0551]$} & {$[0,0481]$} & {$[0,0334]$} & {$[0,0307]$} \\
\hline \multirow{2}{*}{ lubuskie } & 1,0101 & 1,0416 & 0,9483 & 1,0369 \\
\hline & {$[0,0375]$} & {$[0,0447]$} & {$[0,0284]$} & {$[0,0376]$} \\
\hline \multirow{2}{*}{ łódzkie } & $1,3557^{\star \star \star}$ & $1,3009^{\star \star \star}$ & $1,1802^{\star \star \star}$ & $1,0829^{*}$ \\
\hline & {$[0,0449]$} & {$[0,0495]$} & {$[0,0325]$} & {$[0,0391]$} \\
\hline \multirow{2}{*}{ małopolskie } & $1,4943^{\star \star \star}$ & $1,2688^{\star \star \star}$ & 1,0411 & $0,8791^{* * *}$ \\
\hline & {$[0,0498]$} & {$[0,0496]$} & {$[0,0289]$} & {$[0,0319]$} \\
\hline \multirow{2}{*}{ mazowieckie } & $1,6721^{\star \star \star}$ & $1,3394^{\star \star \star}$ & $1,2773^{\star \star \star}$ & $1,0939^{* \star}$ \\
\hline & {$[0,0558]$} & {$[0,0505]$} & {$[0,0348]$} & {$[0,0370]$} \\
\hline \multirow{2}{*}{ opolskie } & $1,3014^{\star \star \star}$ & 1,0638 & $1,0619^{*}$ & 0,9692 \\
\hline & {$[0,0518]$} & {$[0,0431]$} & {$[0,0287]$} & {$[0,0335]$} \\
\hline \multirow{2}{*}{ podkarpackie } & $1,4161^{\star \star *}$ & $1,1070^{\star *}$ & 1,0005 & $0,7992^{\star \star \star}$ \\
\hline & {$[0,0491]$} & {$[0,0435]$} & {$[0,0280]$} & {$[0,0275]$} \\
\hline \multirow{2}{*}{ podlaskie } & $1,7775^{\star \star \star}$ & $1,4337^{\star \star \star}$ & $1,2519^{\star \star \star}$ & 0,9858 \\
\hline & {$[0,0703]$} & {$[0,0623]$} & {$[0,0364]$} & {$[0,0353]$} \\
\hline
\end{tabular}




\begin{tabular}{|c|c|c|c|c|}
\hline \multirow{2}{*}{ pomorskie } & $1,0979^{\star *}$ & $1,1242^{\star *}$ & 1,0141 & 1,0106 \\
\hline & {$[0,0391]$} & {$[0,0461]$} & {$[0,0288]$} & {$[0,0358]$} \\
\hline \multirow{2}{*}{ śląskie } & $1,0738^{\star}$ & $0,9013^{\star \star}$ & $0,8446^{\star \star \star}$ & $0,7306^{\star \star \star}$ \\
\hline & {$[0,0341]$} & {$[0,0331]$} & {$[0,0218]$} & {$[0,0246]$} \\
\hline \multirow{2}{*}{ świętokrzyskie } & $1,1167^{\star \star}$ & $1,2284^{\star \star \star}$ & 1,023 & $0,8850^{\star \star \star}$ \\
\hline & {$[0,0407]$} & {$[0,0512]$} & {$[0,0289]$} & {$[0,0315]$} \\
\hline \multirow{2}{*}{ warmińsko-mazurskie } & $1,1036^{\star *}$ & 0,9992 & $0,8173^{\star \star \star}$ & $0,8054^{\star \star \star}$ \\
\hline & {$[0,0402]$} & {$[0,0403]$} & {$[0,0226]$} & {$[0,0285]$} \\
\hline \multirow{2}{*}{ wielkopolskie } & $1,3391^{\star \star \star}$ & $1,2056^{\star \star \star}$ & $1,0997^{\star \star \star}$ & $1,1071^{\star \star}$ \\
\hline & {$[0,0434]$} & {$[0,0461]$} & {$[0,0297]$} & {$[0,0405]$} \\
\hline \multirow{2}{*}{ zachodniopomorskie } & 1,0153 & $0,8961^{\star *}$ & $0,9255^{\star \star}$ & $0,8494^{\star * *}$ \\
\hline & {$[0,0364]$} & {$[0,0374]$} & {$[0,0272]$} & {$[0,0313]$} \\
\hline \multirow{2}{*}{$\begin{array}{l}\text { stan cywilny: żonaty, } \\
\text { zamężna }\end{array}$} & $1,5187^{\star \star \star}$ & $1,5493^{\star \star \star}$ & $1,6227^{\star \star \star}$ & $1,6541^{\star * *}$ \\
\hline & {$[0,0301]$} & {$[0,0345]$} & {$[0,0241]$} & {$[0,0292]$} \\
\hline \multirow{2}{*}{$\begin{array}{l}\text { stan cywilny: wdowiec, } \\
\text { wdowa }\end{array}$} & $1,2699^{\star \star \star}$ & $1,2557^{\star \star \star}$ & $1,3424^{\star \star \star}$ & $1,2863^{\star \star \star}$ \\
\hline & {$[0,0480]$} & {$[0,0527]$} & {$[0,0374]$} & {$[0,0418]$} \\
\hline \multirow{2}{*}{$\begin{array}{l}\text { stan cywilny: rozwiedzio- } \\
\text { ny(a), w separacji }\end{array}$} & 1,0498 & $1,1611^{\star \star \star}$ & $1,1745^{\star \star \star}$ & $1,3235^{\star \star \star}$ \\
\hline & {$[0,0384]$} & {$[0,0445]$} & {$[0,0295]$} & {$[0,0390]$} \\
\hline \multirow{2}{*}{ miasto $50-100$ tys. } & $0,7701^{\star * \star}$ & $0,7889^{\star \star \star}$ & $0,7383^{\star \star \star}$ & $0,7732^{\star \star \star}$ \\
\hline & {$[0,0197]$} & {$[0,0238]$} & {$[0,0150]$} & {$[0,0190]$} \\
\hline \multirow{2}{*}{ miasto $20-50$ tys. } & $0,7884^{\star \star \star}$ & $0,8374^{\star \star \star}$ & $0,8060^{\star \star \star}$ & $0,7796^{\star \star \star}$ \\
\hline & {$[0,0188]$} & {$[0,0227]$} & {$[0,0147]$} & {$[0,0170]$} \\
\hline \multirow{2}{*}{ miasto $10-20$ tys. } & $0,8581^{\star \star \star}$ & $0,8402^{\star \star \star}$ & $0,8216^{\star \star \star}$ & $0,7153^{\star \star \star}$ \\
\hline & {$[0,0224]$} & {$[0,0262]$} & {$[0,0174]$} & {$[0,0176]$} \\
\hline \multirow{2}{*}{ miasto $5-10$ tys. } & $0,7901^{\star \star \star *}$ & $0,8595^{\star \star \star}$ & $0,7194^{\star \star \star}$ & $0,7673^{\star \star \star}$ \\
\hline & {$[0,0286]$} & {$[0,0348]$} & {$[0,0200]$} & {$[0,0261]$} \\
\hline \multirow{2}{*}{ miasto $2-5$ tys. } & $0,8447^{\star \star \star}$ & $0,6729^{\star \star \star *}$ & $0,7708^{\star \star \star}$ & $0,6967^{\star \star *}$ \\
\hline & {$[0,0375]$} & {$[0,0303]$} & {$[0,0258]$} & {$[0,0278]$} \\
\hline \multirow{2}{*}{ miasto $<2$ tys. } & 0,842 & $0,7010^{\star}$ & $0,4818^{\star \star \star}$ & $0,7852^{\star}$ \\
\hline & {$[0,0912]$} & {$[0,0991]$} & {$[0,0464]$} & {$[0,0949]$} \\
\hline \multirow{2}{*}{ wieś } & $1,3647^{\star \star *}$ & $1,0969^{\star \star \star}$ & 1,0232 & $0,9123^{\star * *}$ \\
\hline & {$[0,0241]$} & {$[0,0222]$} & {$[0,0140]$} & {$[0,0145]$} \\
\hline \multirow{2}{*}{ stała } & $15,5004^{\star \star \star}$ & $37,8867^{\star \star \star}$ & 1,6258 & 0,8005 \\
\hline & {$[9,9561]$} & {$[35,8775]$} & {$[0,9236]$} & {$[0,5525]$} \\
\hline pseudo R2 & 0,1991 & 0,213 & 0,2515 & 0,2925 \\
\hline$N$ & 136240 & 113971 & 251363 & 192964 \\
\hline
\end{tabular}

W nawiasach kwadratowych pod oszacowaniami parametrów podano wartości błędów standardowych. Poziomy istotności oznaczono następująco: ${ }^{* *} p<0,001$; ${ }^{* \star} p<0,01$; ${ }^{*} \mathrm{p}<0,05$

Źródło: opracowanie własne na podstawie danych BAEL, 2004-2016 